\title{
Cheatgrass Invasion - The Below-Ground Connection
}

\author{
Reitstetter, Raven (Corresponding author) \\ North American Deserts Research Center \\ 2089 North 170 West, Tooele, Utah, United States
}

Tel: 1-435-882-2289 E-mail: raven.reitstetter13@alumni.colostate.edu

\author{
Rittenhouse, Larry R. \\ Forest and Rangeland Stewardship, Colorado State University \\ 1472 Campus Delivery, Fort Collins, Colorado 80523, United States
}

Tel: 1-970-491-6911 E-mail: larry.rittenhouse@colostate.edu

Received: Dec. 31, 2016 Accepted: Jan. 11, 2017 Published: May 22, 2017

doi:10.5296/jee.v8i1.10536 URL: https://doi.org/10.5296/jee.v8i1.10536

\begin{abstract}
Plant-soil microbial feedback loops play an important role in the establishment and development of plant communities. Microbial soil communities, including pathogens, plant-growth-promoting rhizobacteria and their reciprocal interactions, can influence plant health and nutrient cycling in many ways. We are proposing a model that accounts for cheatgrass (Bromus tectorum) invasion success and long-term persistence in both disturbed and undisturbed sites. In this model cheatgrass alters soil microbial communities that favor nitrifying microorganisms, resulting in elevated $\mathrm{NO}_{3}{ }^{-}$levels. Increased $\mathrm{NO}_{3}{ }^{-}$levels, coupled with $B$. tectorum life history and climatic and edaphic conditions in the semi-arid western U.S., result in long-term persistence of this invasive annual. In ecosystems that lack major precipitation during the growth season, $B$. tectorum induced shifts in the nitrifier community result in accumulation of plant available nitrogen during the summer when native perennials are primarily dormant. Increased $\mathrm{NO}_{3}^{-}$levels can be efficiently utilized by cheatgrass ahead of native perennials during fall and winter. Restoration and management efforts must be guided by a thorough understanding of soil microbe-cheatgrass interactions to avoid nutrient flushes resulting from freeze-thaw and wet-dry cycles that benefit this invasive grass.
\end{abstract}

Keywords: Cheatgrass, Nitrogen cycling, Invasion, Plant-microbe interactions 


\section{Introduction}

Alien invasive species pose an ever-increasing worldwide problem and have the potential to change plant community composition, nutrient cycling, soil properties, plant productivity and even human health ( Eviner et al., 2010; Mack et al., 2000). In this paper we propose the potential involvement of the microbial community in successful plant invasion. Bromus tectorum has been introduced into the western U.S. in the late 1800s and has since invaded millions of hectares in the Intermountain West of the U.S. (Belnap \& Phillips, 2001; Eviner et al., 2010; Hulbert, 1955). Cheatgrass is a winter annual that germinates in the fall through spring and completes seed maturation in June, ahead of most perennial grasses. It is usually completely senesced by the end of June (Klemmedson \& Smith, 1964; Mack \& Pyke, 1983; Thill et al., 1984).

Often physiological properties and the life history of B. tectorum and its interactions with soil abiotic components are used to explain its success as a persistent invader (Belnap \& Phillips, 2001; Hulbert, 1955; Norton et al., 2004; Thill et al., 1984). Furthermore, an increase in the fire cycle induced by cheatgrass has been implicated in supporting invasion (D'Antonio \& Vitousek, 1992). However, these parameters do not completely explain the long-term success of cheatgrass as a dominant invasive species in western rangelands. How would we, for example, explain the lack of successional progression and re-colonization by native plants in sites that are not affected by frequent fire cycles and that experience wet periods during late spring and summer - conditions that should favor the establishment of perennial species? Interestingly Klironomos (2002) points out that competition, resource partitioning, dispersal ability and predation tolerance are not sufficient indicators to account for relative abundance of plant species at the community level. He argues that plants have the ability to structure soil biota that in turn have the ability to regulate plant community structure.

\section{Plant-Soil Microbial Community Interactions}

Soil microorganisms are an integral part of ecosystems and play a central role in nutrient cycling. They have been in the past mostly neglected as a direct player in plant soil interactions. A surprising fact given that one gram of soil can contain $10^{9}$ microbes with at least 10,000 different species (Gans et al., 2005). Plants and soil biota are linked through intricate feedback mechanisms that can manifest themselves in positive or negative ways (Wardle et al., 2004). Several studies have shown that plant community composition can change the soil microbial composition (Bardgett et al., 1999; Grayston et al., 1998, 2001; Innes et al., 2004; Porazinska et al., 2003). Conversely, microorganisms can enhance plant growth as in the case of mutualistic symbionts and plant-growth-promoting bacteria, or impact plants in a negative manner as in the case of plant pathogens (Griffiths et al., 1999; Lugtenberg \& Kamilova, 2009; Mabood et al., 2008; Rudrappa et al., 2008).

More specifically, in the case of B. tectorum Bolton et al. (1993) noted an increase in culturable soil heterotrophs, actinomycetes and fungi in a cheatgrass invaded Great Basin shrub-steppe community. In a southwestern Utah grassland community Belnap and Phillips (2001) observed an increase in both soil fungal numbers and species in B. tectorum invaded sites. In a later study utilizing molecular biology tools Hawkes et al. (2006) described a shift 
from Glomus spp. mycorrhizal fungi to saprophytic and pathogenic genera in the invaded sites. In a different location Kuske et al. (2002) analyzed soil microbial communities with terminal restriction fragment analysis and identified distinct bacterial communities between biological soil crust covered soils, native grass communities and cheatgrass invaded sites.

Nutrient cycling has also been shown to be impacted by B. tectorum invasion. Total soil nitrogen and extractable nitrogen has been found to increase in several studies (Belnap et al., 2005; Blank, 2008; Bolton et al., 1990, 1993; Booth et al., 2003; Hooker et al., 2008; Norton et al., 2004; Stark \& Norton, 2015), although Svejcar and Sheley (2001) observed no change. Looking at the individual nitrogen ions $\mathrm{NH}_{4}{ }^{+}$and $\mathrm{NO}_{3}{ }^{-}$, cheatgrass invaded sites ranged from increased soil concentrations to no change to decreased amounts (Adair and Burke, 2010; Belnap et al., 2005; Blank, 2008; Booth et al., 2003; Evans et al., 2001; Hooker et al., 2008; Norton et al., 2004; Stark \& Norton, 2015; Svejcar \& Sheley, 2001). The observed variability can be due to different sampling methods and sampling dates. For example, soil $\mathrm{NO}_{3}{ }^{-}$levels have been shown to vary throughout the year and peak during summer (Adair and Burke, 2010; Booth et al., 2003; Hooker et al., 2008; Svejcar \& Sheley, 2001).

\section{Invasion Success of Bromus tectorum and Below-Ground Interactions}

How can plant-soil microbial interactions be relevant to invasion of western U.S. lands by $B$. tectorum? In addition to physiological and phenotypic traits cheatgrass interacts with soil microbial communities inducing shifts in microbial populations (Figure 1). Plants provide carbon rich nutrient sources to the soil microbial community in the form of root exudates, sloughing off of root cells and root hair death (Hartmann et al.. 2009; Mabood et al., 2008). Besides supplying carbon rich compounds, plants release antimicrobial metabolites in their exudates that can be species specific (Dakora \& Phillips, 2002; Griffiths et al., 1999). Therefore, plants may be able to engineer site conditions utilizing soil microbes to provide positive feedbacks. Although these potential plant microbe interactions have not been specifically investigated in B. tectorum dominated communities, the observed changes in microbial communities, when compared to native grass and shrub associations, support the hypothesis of cheatgrass soil microbe interactions (Belnap \& Phillips, 2001; Bolton et al., 1993; Booth et al., 2003; Hawkes et al., 2006). Klironomos (2002) suggested a release from microbial pathogens as a potential mechanism for the success of invasives. This has also been proposed to play a role in cheatgrass invasions and may find support in the observation that cheatgrass was found to have less fungal infections than native grasses (Belnap \& Phillips, 2001). Another potential mechanism, that is not necessarily exclusive from a proposed pathogen release hypothesis, is the association of plants with plant-growth-promoting rhizobacteria that colonize the rhizosphere and protect plant roots from pathogenic microorganisms through competition with pathogenic bacteria or result in induced systemic resistance in plants (Lugtenberg \& Kamilova, 2009). Specific plant microbe associations can be the result of root exudate composition unique to plants benefitting from interactions with plant-growth-promoting bacteria. Interestingly, cheatgrass invasion has been found to increase fungal numbers, fungal species and actinomycetes (Belnap \& Phillips, 2001; Bolton et al., 1993). Besides being involved in the detritus decomposer chain, actinomycetes have members, such as the streptomycetes, that produce a variety of antibiotics and have also been 
implicated in the induction of plant defenses (Mabood et al., 2008, Tarkka et al., 2008).

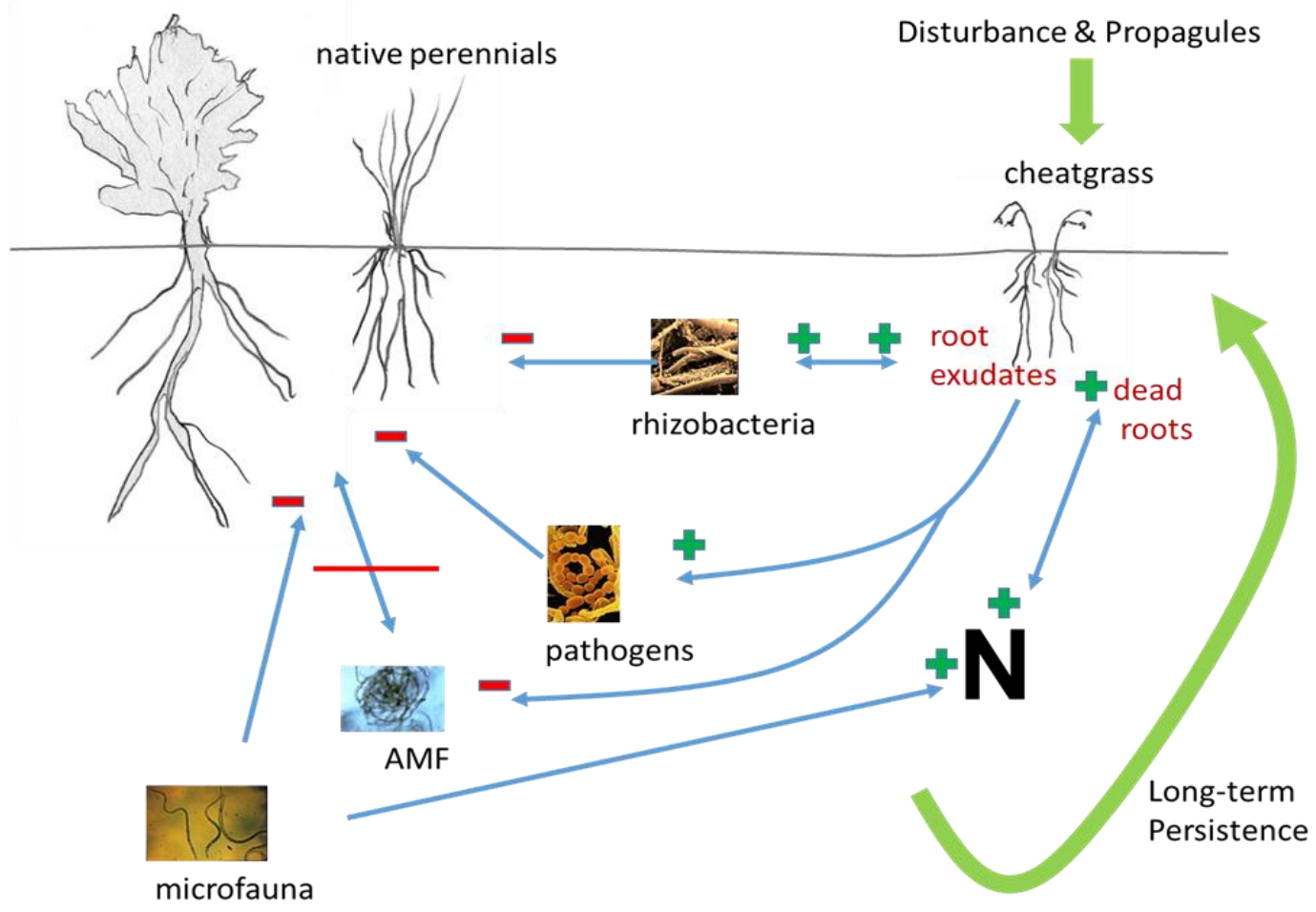

Figure 1. Belowground feedbacks driven by Bromus tectorum invasion. Belowground microbial communities are engaged in an intricate feedback network with each other and plants in the aboveground domain. The feedback interactions can be positive (+) as in the case of plant growth promoting rhizobacteria, neutral, or negative (-) as with pathogens. Cheatgrass invasion can drive belowground changes in microbe communities through dead root mass or root exudates. Altered belowground communities may exert direct negative feedbacks (-) on perennial shrubs and bunchgrasses or have indirect effects through modification of communities supporting perennial plant establishment and survival.

An increase in total soil nitrogen has been described in the majority of studies looking at the impacts of $B$. tectorum invasion. Looking at changes in the individual soil available nitrogen forms $\mathrm{NH}_{4}{ }^{+}$and $\mathrm{NO}_{3}{ }^{-}$the picture becomes more complex, though. The increase in $\mathrm{NH}_{4}{ }^{+}$ observed in some studies, together with increased nitrogen mineralization rates indicate a positive response by microbial populations to additional plant mass provided through cheatgrass invasion with subsequent increase in ammonification. Bromus tectorum invasion changes land cover from intermittent plant cover by shrubs and bunchgrasses with bare, or biological soil crust covered interspaces to a homogeneous annual grass cover. Belnap and Philips (2001) have observed an increase in aboveground plant litter by a factor of 2.2 to 2.8 in semi-arid grasslands invaded by $B$. tectorum. Although nutrient input from leaf litter composition is considered to be negligible in arid and semi-arid environments (Austin \& Vivanco, 2006; Collins et al., 2008) cheatgrass provides a large root mass that is turned over on an annual basis (Belnap \& Phillips, 2001; Norton et al., 2004). Decomposable organic matter in the form of cheatgrass roots provides soil microbial communities with 
increased substrate availability for mineralization that subsequently becomes available as $\mathrm{NH}_{4}{ }^{+}$. Observed increases in bacterial biomass, bacterial heterotrophs, actinomycetes and soil fungi support this hypothesis. Actinomycetes can break down complex polymers such as chitin and lignin and members of this group have been shown to mediate infections by plant pathogens while other actinomycetes show plant protecting properties through the induction of plant resistance (Schrey \& Tarkka, 2008). The increase of acidobacteria observed by Kuske et al. (2002) is of similar interest. Although the phylum acidobacteria has only recently been described and very little information is available about this bacterial group, its members are primarily found in soil and appear to be involved in the cycling of complex substrates such as cellulose and chitin and have been postulated to be able to tolerate fluctuations in soil water content (Ward et al., 2009). Cheatgrass has been shown to form a dense shallow, very fine root system (Belnap \& Phillips, 2001; Norton et al., 2004) and the roots display a relatively high C:N ratio comparable to native perennials (Blank, 2008; Evans et al., 2001; Paschke et al., 2000, Svejcar \& Sheley, 2001). Despite its high lignin content (Evans et al., 2001) this root mass provides nutrients for the detritus food chain, especially organisms such as fungi and actinomycetes, that can readily utilize recalcitrant plant material (Ward et al., 2009; Schrey \& Tarkka, 2008; Sylvia et al., 2005). Several studies have shown that the carbon and nitrogen content of $B$. tectorum roots is similar to native perennial grasses and shrubs and can, therefore, serve as a suitable substrate for mineralization (Evans et al., 2001; Monaco et al., 2003; Paschke et al., 2000). Furthermore, the alkaline conditions in arid and semi-arid lands of the western U.S. favor high oxidative enzyme potentials (Collins et al., 2008). Oxidative soil enzymes are excreted by soil microorganisms and facilitate the breakdown of organic matter in arid soils at water potentials that would restrict microbial activity.

The above described mechanisms result in elevated soil $\mathrm{NH}_{4}{ }^{+}$levels. Why do we then not see a consistent increase in $\mathrm{NH}_{4}{ }^{+}$as a result of cheatgrass invasion? Three possible scenarios can account for this. Ammonium uptake by plants or microorganisms, $\mathrm{NH}_{4}{ }^{+}$volatization or nitrification. Little information about $\mathrm{NH}_{4}{ }^{+}$utilization by sagebrush steppe plant communities is available. Ammonium volatization can be significant in alkaline soils because ionic $\mathrm{NH}_{4}{ }^{+}$is transformed into gaseous $\mathrm{NH}_{3}$ at high $\mathrm{pH}$ (Schlesinger et al., 1990). We would like to argue that the major route for $\mathrm{NH}_{4}{ }^{+}$consumption in cheatgrass invaded sites is through nitrification. This hypothesis is supported by findings of increased soil $\mathrm{NO}_{3}{ }^{-}$levels, especially during the summer when cheatgrass has senesced and perennial grasses are dormant due to lack of precipitation and, therefore, increased $\mathrm{NO}_{3}{ }^{-}$cannot be utilized by plants and is left accumulating in the soil. Hawkes et al. (2005) have found that exotic annual grasses grown in field plot experiments in California doubled nitrification rates compared to native grasses and forbs. This increase in nitrification was accompanied by the development of distinct ammonia-oxidizing bacteria communities in soils with exotic annuals compared to natives and bare soil. Nitrification of $\mathrm{NH}_{4}{ }^{+}$to $\mathrm{NO}_{3}{ }^{-}$is a two-step process that involves the production of $\mathrm{NO}_{2}^{-}$by ammonia oxidizing bacteria (AOB) which in turn serves as substrate for nitrite oxidizing bacteria (NOB) that produce $\mathrm{NO}_{3}{ }^{-}$(Figure 2). Both bacterial groups are chemolithoautotrophs of oxygenic environments that utilize the inorganic nitrogen compounds as energy sources and $\mathrm{CO}_{2}$ as their carbon source (Prosser, 2011; Starkenburg et 
al. 2011). The combination of alkaline soils in the western U.S. and biomass input from cheatgrass invasion form an advantageous environment for nitrifiers. Norton and et al. (2004) described reduced bulk density of cheatgrass invaded soils and Kyle et al. (2007) demonstrated that $B$. tectorum cover is negatively related to soil compaction, but not with native plant cover. This would favor gas exchange and provide a favorable $\mathrm{O}_{2}$ and $\mathrm{CO}_{2}$ environment for AOBs and NOBs. Furthermore, the alkaline environment of the soils does serve as a buffer system for the nitrification process, which liberates protons. Acidic environments have been shown to inhibit nitrifiers (Prosser, 2011; Starkenburg et al. 2011). Differences in soil characteristics may also explain differences in $\mathrm{NO}_{3}^{-}$levels found in the field. Ammonium can be adsorbed at negative mineral surfaces as found for example in clays, leading to local accumulation of $\mathrm{NH}_{4}{ }^{+}$(Prosser, 2011). This together with the finding that AOBs form biofilms on the surface of soil particles can provide natural "nitrification reactors", where the efficient coupling of $\mathrm{NO}_{2}{ }^{-}$oxidation between AOBs and NOBs occurs in a capsular matrix that hosts both bacterial groups (Starkenburg et al., 2011). Kindaichi et al. (2004) have shown a close spatial association of nitrifying bacteria and heterotrophic bacteria in biofilms, forming a spatially coupled system for oxidation of $\mathrm{NH}_{4}{ }^{+}$to $\mathrm{NO}_{3}{ }^{-}$. It is conceivable that nitrifier-heterotroph aggregates do exist on soil particles and plant root surfaces similar to biofilms formed by plant-growth-promoting rhizobacteria and pathogens (Bais et al., 2006; Lugtenberg \& Kamilova, 2009). Nitrifying bacteria could be accumulated and primed by $B$. tectorum roots through the interaction with root exudates. A direct and specific interaction can occur through low molecular organic substrates. Although both AOBs and NOBs have been considered to be obligate chemolithoautotrophs, recent evidence is accumulating that they can utilize organic compounds for growth, albeit at much lower growth rates than with $\mathrm{NH}_{4}{ }^{+}$or $\mathrm{NO}_{2}{ }^{-}$(Sayavedra-Soto \& Arp, 2011; Starkenburg et al., 2011). The utilization of organic substrates is interpreted as a survival strategy during low availability of inorganic nitrogen. Primed nitrifier-heterotroph communities would then be in place within the cheatgrass rhizosphere to mineralize dead root matter and turn it into $\mathrm{NO}_{3}{ }^{-}$ upon plant senescence. An argument that would speak against this scenario is the depletion of soil moisture towards the end of spring and early summer that, besides restricting plant growth, may negatively affect bacterial activity. However, Davidson et al. (1990) have shown nitrification activity down to a water potential of $-1.5 \mathrm{MPa}$ in a California annual grassland. Also of interest is the recent finding that prokaryotes of the domain Archaea have the ability to oxidize $\mathrm{NH}_{4}{ }^{+}$and have been implicated as major contributors to nitrogen cycling (Urakawa et al., 2011). They have the ability to utilize heterotrophic carbon sources similar to AOB. It is intriguing to note that Archaea are best known for inhabiting extreme environments, from hot geothermal springs to haline soils. The $\mathrm{NO}_{3}{ }^{-}$thus accumulated in arid and semi-arid sites during the summer will be available for cheatgrass seedlings in the fall and spring when favorable soil water conditions allow for germination and seedling establishment. 


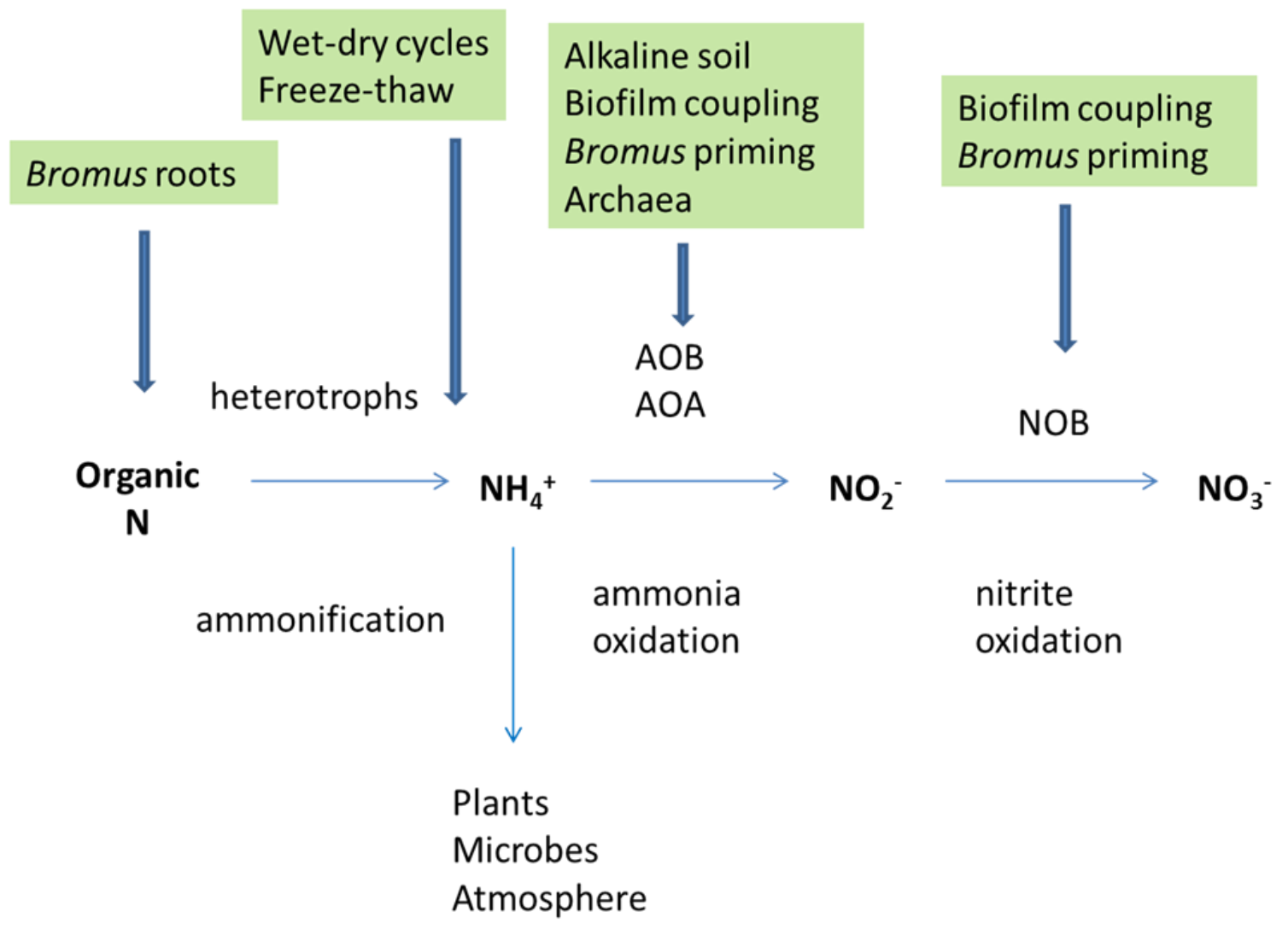

Figure 2. Effects of B. tectorum invasion on nitrogen cycling. The additional biomass provided by cheatgrass roots is being turned over on an annual basis, providing substrate for nitrifiers in the form of $\mathrm{NH}_{4}{ }^{+}$. Abiotic, edaphic conditions and B. tectorum-soil microbe interactions favor nitrifiers and result in increased $\mathrm{NO}_{3}{ }^{-}$production.

Wet-dry cycles can also increase nitrogen cycling. Saetre and Stark (2005) have shown that re-wetting of soils in the Intermountain West increases $\mathrm{NO}_{3}{ }^{-}$under cheatgrass to a much greater extent than under sagebrush. In the spring $B$. tectorum may benefit from nitrogen flushes due to freeze-thaw cycles that have been demonstrated in alpine environments (Lipson et al., 1999). Bilbrough and Caldwell (1997) have shown that cheatgrass can exploit spring time nitrogen pulses in a Great Basin environment. Although Pseudoroegneria spicata, and to a lesser extent Artemisia tridentata ssp. vaseyana, were also able to benefit from nitrogen pulses their response set in much later compared to B. tectorum. Therefore, cheatgrass appears to be able to utilize spring-time nitrogen pulses more efficiently than native vegetation.

The coupling of cheatgrass establishment, senescence, and $\mathrm{NO}_{3}{ }^{-}$accumulation results in a positive feedback between $B$. tectorum and the soil microbial community. It is of interest that cheatgrass does not show an expansion in the Great Plains region that is as dramatic as in the Intermountain West and infestations remain very limited to heavily disturbed sites (Bradford 
\& Lauenroth, 2006). The explanation for this could be the fact that warm season grasses dominate in the Great Plains region. Elevated summer $\mathrm{NO}_{3}{ }^{-}$would most likely be utilized by warm season grasses that are in their peak growth season during this time in the Great Plains.

Changes in microbial communities as a result of cheatgrass invasion can alter the competitiveness of $B$. tectorum with native bunchgrasses and shrubs and provide an explanation for the observations of cheatgrass invading sites with no apparent or documented anthropogenic disturbance. In this scenario cheatgrass may take advantage of increased nutrient and water availability by colonizing islands of fertility, using shrubs and bunchgrasses as nurseries. Spatial differences in nutrient distribution within perennial shrub-grass communities have been documented (Schlesinger et al., 1996). Ibañez and Schupp (2001) have found a positive effect of Artemisia tridentata on seedling establishment of Cercocarpus in dry years, but not in wet years with sagebrush seemingly acting as a nursery shrub. However, the nursery effect is variable and may be dependent on the species involved. For example, a study looking at seedling establishment and survival of Agropyron desertorum and Pseudoroegneria spicata under sagebrush showed a negative interaction (Huber-Sannwald \& Pyke 2005). Once established in the vicinity of shrubs cheatgrass can re-engineer soil site conditions in its favor through modification of the soil microbial communities, while at the same time orchestrating negative feedbacks between the soil biota and perennial species leading to the subsequent demise of perennials. Hawkes et al. (2006) have documented a shift from arbuscular mycorrhizal fungal Glomus species to the saprophytic and pathogenic fungi Alternaria, Phoma, and Sporobolomyces in cheatgrass invaded grasslands. Once locally established, cheatgrass modifies soil conditions from the colonization centers radiating out into adjacent areas not covered by vegetation through belowground plant-microbe interactions, providing the conditions for subsequent expansion. Competing bunchgrasses are gradually displaced through competition for resources.

\section{Lessons for Rangeland Rehabilitation}

A thorough understanding of plant-soil microbe interactions is not only essential for understanding resistance, resilience and changes in ecosystems, but will also assist land managers in rehabilitation efforts of invaded areas. The interactions described above may help to understand the continued success of cheatgrass as well as challenges encountered with rehabilitation projects targeting $B$. tectorum invaded sites. Approaches to rehabilitate areas invaded by cheatgrass and other invasives have included the addition of carbon in the form of sugar, straw, sawdust, mulch, biochar or activated charcoal (Beckstead \& Augspurger, 2004; Kulmatiski, 2011; Mazzola et al., 2008; Ohsowski et al., 2012, Paschke et al., 2000). The idea behind these applications is that added carbon immobilizes nitrogen in soil bacteria by increasing the $\mathrm{C} / \mathrm{N}$ ratio (Perry et al., 2010). This approach, though, has not always been successful in long-term restoration of native or non-native perennials and studies using woodchips from masticated pinyon-juniper woodland even resulted in increased B. tectorum cover (Mazzola et al., 2008; Owen et al. 2009). The timing of carbon applications is crucial since nitrogen accumulated in soil microbes can be released by freeze-thaw or wet-dry cycles resulting in nutrient flushes that, if superimposed on cheatgrass active growth periods, could foster the growth of this invasive instead of decreasing it. Pulsed application of carbon in the 
form of sugar has been shown to result in the death of half of the microbial biomass within 20 days. The decline in microbes was likely due to the carbon pulse breaking dormancy of soil microorganisms that subsequently died due to nutrient exhaustion ( $\mathrm{Wu}$ et al., 1993). This finding may point at the need of continuous low level carbon addition in order to be effective in immobilizing nitrogen long-term. This hypothesis may be supported by the fact that sucrose applications spread out evenly from April to October resulted in successful restoration of short-grass steppe in Colorado (Paschke et al., 2000).

Another approach for controlling B. tectorum invasion is the use of cheatgrass-specific pathogens. If cheatgrass has evaded its natural pathogens with the invasion of new territory the introduction of specific pathogens can restore the competitiveness of native species. Promising research has shown the potential of Pseudomonas fluorescens D7 to reduce root growth in B. tectorum while not in most other species tested (Kennedy et al., 2001). Meyer et al. (2008) have investigated three pathogens - head smut (Ustilago bullata), chestnut bunt (Tilletia fusca), and black-fingers-of death (Pyrenophora semeniperda) - in order to explore their ability to selectively attack B. tectorum seeds or seed production. An approach targeting cheatgrass seeds can be used in conjunction with other control and restoration efforts to deplete the cheatgrass seedbank. However, a thorough understanding of potential effects of introduced microbes on the overall ecosystem function is necessary since risks exist with this kind of control approach (Van der Putten et al., 2007). A chemical intervention, although indirect, could be the application of the agricultural ammonia oxidation inhibitor nitrapyrin, although its efficacy needs to be tested in rangeland environments, since it was shown that biofilm formation reduces its effect (Prosser, 2011; Sayavedra-Soto \& Arp, 2011).

\section{Conclusions and Outlook}

We are currently in the descriptive phase for understanding microbial soil communities and their interactions with plants. In order to extend our knowledge to the functional level we need to develop approaches that tie functional measurements to microbial identities. Past approaches at this were limited to microorganisms that can be isolated and maintained in culture. New DNA-based approaches have extended our reach beyond non-culturable organisms and these activities need to be linked to functional analyses in order to gain a framework for soil microbe-plant interactions and the players involved. Such a framework will enable us to describe, analyze and predict soil microbe-plant interactions driven by plant invasions and will provide scientists and managers with the tools to better manage invasion-prone environments as well as target microbe-plant interactions for rehabilitation purposes. We suggest that $B$. tectorum invasion in the western U.S. modifies the soil microbial composition and nitrogen cycles in its favor. Cheatgrass interacts with soil microbes to change nitrogen cycling with the result of increased $\mathrm{NO}_{3}{ }^{-}$due to positive interactions with nitrifying bacteria. Bromus can capitalize on increased $\mathrm{NO}_{3}{ }^{-}$levels in the fall, as well as on nitrogen pulses in the spring time because its life history is synchronized with the timing of these events. Furthermore, B. tectorum may interact more directly with the soil microbial communities by benefiting from plant-growth-promoting rhizobacteria, release from pathogens, and/or feedbacks with the soil microbial community to develop negative feedbacks, such as reduction in arbuscular mycorrhizal fungi, for native plant species. These 
hypotheses are testable and may spur future research into the interaction between $B$. tectorum and soil microbes and its role as a successful invader in the western US. The insights into cheatgrass-soil microbe-native plant interactions also allows for fine-tuning existing management approaches.

\section{Acknowledgement}

We would like to thanks Drs. Mark Paschke and Kraig Peel for stimulating discussions pertaining the subject matter.

\section{References}

Adair, E. C., \& Burke, I. C. (2010). Plant phenology and life span influence soil pool dynamics: Bromus tectorum invasion of perennial $\mathrm{C}_{3}-\mathrm{C}_{4}$ grass communities. Plant Soil, 335 , 255-269. http://dx.doi.org/10.1007/s11104-010-0413-3

Austin, A. T., \& Vivanco, L. (2006). Plant litter decompsition in a semi-arid ecosystem controlled by photodegradation. Nature, 442, 555-558. http://dx.doi.org/10.1038/nature05038

Bais, H., Weir, T., Perry, L., Gilroy, S., \& Vivanco, J. (2006). The role of root exudates in rhizosphere interactions with plants and other organisms. Annual Review of Plant Biology, 57, 233-266. https//dx.doi.org/10.1146/annurev.arplant.57.032905.105159

Bardgett, R.D., Mawdsley, J.L., Edwards, S., Hobbs, P.J., Rodwell, J.S., \& Davies W.J. (1999). Plant species and nitrogen effects on soil biological properties of temperate upland grasslands. Functional Ecology, 650-660. http://dx.doi.org/10.1046/j.1365-2435.1999.00362.x

Beckstead, J., \& Augspurger, C. (2004). An experimental test of resistance to cheatgrass invasion: limiting resources at different life stages. Biological Invasions, 6, 417-432. http://dx.doi.org/10.1023/B:BINV.0000041557.92285.43

Belnap, J., \& Phillips S. L. (2001). Siol biota in an ungrazed grassland: Response to annual grass (Bromus tectorum) invasion. Ecological Applications, 11(5), 1261-1275. http://dx.doi.org/10.1890/1051-0761(2001)011[1261:SBIAUG]2.0.CO;2

Belnap, J., Phillips, S. L., Sherrod, S. K., \&Moldenke A. (2005). Soil biota can change after exotic plant invasion: does this affect ecosystem processes? Ecology, 86(11), 3007-3017. http://dx.doi.org/10.1890/05-0333

Bilbrough, C. J., \& Caldwell, M. M. (1997). Exploitation of springtime ephemeral N pulses by six Great Basin plant species. Ecology, 78(1), 231-243. http://dx.doi.org/10.2307/2265992

Blank, R. R. (2008). Biogeochemistry of plant invasion: A case study with downy brome (Bromus tectorum). Invasive Plant Science and Management, 1(2), 226-238. http://dx.doi.org/10.1614/IPSM-07-026.1

Bolton, H., Smith, J. L., \& Link, S. O. (1993). Soil microbial biomass and activity of a disturbed and undisturbed shrub-steppe ecosystem. Soil Biology and Biochemistry, 25(5), 545-552. http://dx.doi.org/10.1016/0038-0717(93)90192-E 
Bolton, H., Smith, J. L., \& Wildung, R. E. (1990). Nitrogen mineralization potentials of shrub-steppe soils with different disturbance histories. Soil Science Society of America Journal, 54, 887-891. http://dx.doi.org/10.2136/sssaj1990.03615995005400030046x

Booth, M. S., Stark, J. M., \& Caldwell, M. M. (2003). Inorganic N turnover and availability in annual- and perennial-dominated soils in a nothern Utah shrub-steppe ecosystem. Biogeochemistry, 66, 311-330. http://dx.doi.org/10.1023/B:BIOG.0000005340.47365.61

Bradford, J. B., \& Lauenroth, W. K. (2006). Controls over invasion of Bromus tectorum: The importance of climate, soil, disturbance and seed availability. Journal of Vegetation Science, 17, 693-704. http://dx.doi.org/10.1658/1100-9233(2006)17[693:coiobt]2.0.co;2

Collins, S. L., Sinsabaugh, R. L., Crenshaw, C., Green, L., Porras-Alfaro, A., Stursova, M., \& Zeglin, L. H. (2008). Pulse dynamics and microbial processes in aridland ecosystems. Journal of Ecology, 96, 413-420. http://dx.doi.org/10.1111/j.1365-2745.2008.01362.x

Dakora, F. D., \& Phillips, D. A. (2002). Root exudates as mediators of mineral acquisition in low-nutrient environments. http://doi.org/10.1023/A:1020809400075

D'Antonio, C. M., \& Vitousek, P. M. (1992). Biological invasions by exotic grasses, the grass/fire cycle, and global change. Annual Review of Ecology and Systematics, 23, 63-87. http://dx.doi.org/10.1146/annurev.es.23.110192.000431

Davidson, E. A., Stark, J. M., \& Firestone, M. K. (1990). Microbial production and consumption of nitrate in an annual grassland. Ecology, 71(5), 1968-1975. http://dx.doi.org/10.2307/1937605

Evans, H., Rimer, R., Sperry, L., \& Belnap, J. (2001). Exotic plant invasion alters nitrogen dynamics in an arid grassland. Ecological Applications, 11(5), 1301-1310. http://dx.doi.org/10.1890/1051-0761(2001)011[1301:EPIAND]2.0.CO;2

Eviner, V. T., Hoskinson, S. A., \& Hawkes, C. V. (2010). Ecosystem impacts of exotic plants can feed back to increase invasion in western US rangelands. Rangelands, 32(1), 21-31. http://dx.doi.org/10.2111/RANGELANDS-D-09-00005.1

Gans, J., Wolinsky, M., \& Dunbar, J. (2005). Computational improvements reveal great bacterial diversity and high metal toxicity in soil. Science, 309(5739), 1387-1390. http://dx.doi.org/10.1126/science. 1112665

Grayston, S. J., Griffith, G. S., Mawdsley, J. L., Campbell, C. D., \& Bardgett, R. D. (2001). Accounting for variability in soil microbial communities of temperate upland grassland ecosystems. Soil Biology and Biochemistry, 33, 533-551. http://Dx.doi.org/10.1016/S0038-0717(00)00194-2

Grayston, S. J., Wang, S., Campbell, C. D., \& Edwards, A. C. (1998). Selective influence of plant species on microbial diversity in the rhizospere. Soil Biology and Biochemistry, 30(3), 369-378. http://dx.doi.org/10.1016/S0038-0717(97)00124-7

Griffiths, B. S., Ritz, K., Ebblewhite, N., \& Dobson, G. (1999). Soil microbial community 
structure: Effects of substrate loading rates. Soil Biology and Biochemistry, 31, 145-153. http://dx.doi.org/10.1016/S0038-0717(98)00117-5

Hartmann, A., Schmid, M., van Tuinen, D., \& Berg, G. (2009). Plant-driven selection of microbes. Plant and Soil, 321(1), 235-257. http://dx.doi.org/10.1007/s11104-008-9814-y

Hawkes, C. V., Belnap, J., D'Antonio, C. D., \& Firestone, M. K. (2006). Arbuscular mycorrhizal assemblages in native plant roots change in the presence of invasive exotic grasses. Plant and Soil, 281, 369-380. http://dx.doi.org/10.1007/s11104-005-4826-3

Hawkes, C. V., Wren, I. F., Herman, D. J., \& Firestone, M. K. (2005). Plant invasion alters nitrogen cycling by modifying the soil nitrifying community. Ecology Letters, 8, 976-985. http://dx.doi.org/10.1111/j.1461-0248.2005.00802.x

Hooker, T. D., Stark, J. M., Norton, U., Leffler, A. J., Peek, M., \& Ryel, R. (2008). Distribution of ecosystem $\mathrm{C}$ and $\mathrm{N}$ within contrasting vegetation types in a semiarid rangeland in the Great Basin, USA. Biogeochemistry, 90(3), 291-308. http://dx.doi.org/ 10.1007/s10533-008-9254-z

Huber-Sannwald, E., \& Pyke, D. A. (2005). Establishing native grasses in a big sagebrush-dominated site: an intermediate restoration step. Restoration Ecology, 13, 292-301. http://dx.doi.org/10.1111/j.1526-100X.2005.00037.x

Hulbert, L. C. (1955). Ecological studies of Bromus tectorum and other annual bromegrasses. Ecological Monographs, 25(2), 181-213. http://dx.doi.org/10.2307/1943550

Ibañez, I., \& Schupp, E. W. (2001). Positive and negative interactions between environmental conditions affecting Cercocarpus ledifolius seedling survival. Oecologia, 129, 543-550. http://dx.doi.org/10.1007/s004420100757

Innes, L., Hobbs, P.J., \& Bardgett, R.D. (2004) The impacts of individual plant species on rhizoshere microbial communities in soils of different fertility. Biology and Fertility of Soils, 40(1), 7-13. http://dx.doi.org/10.1007/s00374-004-0748-0

Kennedy, A. C., Johnson, B. N., \& Stubbs, T. L. (2001). Host range of a deleterious rhizobacterium for biological control of downy brome. Weed Science, 49, 792-797. http://dx.doi.org/10.1614/0043-1745(2001)049[0792:HROADR]2.0.CO;2

Kindaichi, T., Ito, T., \& Okabe, S. (2004). Ecophysiological interaction between nitrifying bacteria and heterotrophic bacteria in autotrophic nitrifying biofilms as determined by microautoradiography-fluorescence in situ hybridization. Applied and Environmental Microbiology, 70(3), 1641-1650. http://dx.doi.org/10.1128/AEM.70.3.1641-1650.2004

Klemmedson, J. O., \& Smith, J. G. (1964). Cheatgrass (Bromus tectorum L.). The Botanical Review, 30(2), 226-262. http://dx.doi.org/10.1007/BF02858603

Klironomos, J. N. (2002). Feedback with soil biota contributes to plant rarity and invasiveness in communities. Nature, 417, 67-70. http://dx.doi.org/10.1038/417067a

Kulmatiski, A. (2011). Changing soils to manage plant communities: Activated carbon as a 
restoration tool in ex-arable fields. Restoration Ecology, 19(101), 102-110. http://dx.doi.org/ 10.1111/j.1526-100X.2009.00632.x

Kuske, C., Ticknor, L., Miller, M., Dunbar, J., Davis, J., Barns, S., \& Belnap, J. (2002). Comparison of soil bacterial communities in rhizospheres of three plant species and the interspaces in an arid grassland. Applied and environmental microbiology , 68(4), 1854-1863. http://dx.doi.org/10.1128/AEM.68.4.1854-1863.2002

Kyle, G. P., Beard, K. H., \& Kulmatiski, A. (2007). Reduced soil compaction enhances establishment of non-native plant species. Plant Ecology, 193, 223-232. http://dx.doi.org/ 10.1007/s11258-006-9260-y

Lipson, D. A., Schmidt, S. K., \& Monson, R. K. (1999). Links between microbial population dynamics and nitrogen availability in an alpine ecosystem. Ecology, 80(5), 1623-1631. http://dx.doi.org/ 10.1890/0012-9658(1999)080[1623:LBMPDA]2.0.CO;2

Lugtenberg, B., \& Kamilova, F. (2009). Plant-growth-promoting rhizobacteria. Annual Review of Microbiology, 63, 541-556. http://dx.doi.org/10.1146/annurev.micro.62.081307.162918

Mabood, F., Jung, W. J., \& Smith, D. L. (2008). Signals in the underground: Microbial signaling and plant productivity. In C. S. Nautiyal \& P. Dion (eds.), Molecular Mechanisms of Plant and Microbe Coexistence (pp. 291-318). Berlin: Springer

Mack, R. N., \& Pyke, D. A. (1983). The demography of Bromus tectorum: Variation in time and space. Journal of Ecology, 71(1), 69-93. http://dx.doi.org/10.2307/2259964

Mack, R. N., Simberloff, D., Lonsdale, M. W., Evans, H., Clout, M., \& Bazzaz, F. A. (2000). Biotic invasions: causes, epidemiology, global consequences, and control. Ecological Applications, $10(3)$ 689-710. http://dx.doi.org/10.1890/1051-0761(2000)010[0689:BICEGC]2.0.CO;2

Mazzola, M. B., Allcock, K. G., Chambers, J. C., Blank, R. R., Schupp, E. W., Doescher, P. S., \& Nowak, R. S. (2008). Effects of nitrogen availability and cheatgrass competition on the establishment of Vavilov Siberian Wheatgrass. Rangeland Ecology and Management, 61, 475-484. http://dx.doi.org/10.2111/07-133.1

Meyer, S. E., Nelson, D. L., Clement, S., and Beckstead, J. (2008). Cheatgrass (Bromus tectorum) biocontrol using indigenous fungal pathogens. USDA RMRS-P-52, 61-67.

Monaco, T. A., Johnson, D. A., Norton, J. M., Jones, T. A., Connors, K. J., Norton, J. B., \& Redinbaugh, M. B. (2003). Contrasting responses of Intermountain West grasses to soil nitrogen. Journal of Range Management, 56, 282-290. http://dx.doi.org/10.2307/4003820

Norton, J. B., Monaco, T. A., Norton, J. M., Johnson D. A., \& Jones, T. A. (2004). Soil morphology and organic matter dynamics under cheatgrass and sagebrush-steppe plant communities. Journal of Arid Environments, 57, 445-466. http://dx.doi.org/10.1016/S0140-1963(03)00104-6 
Ohsowski, B. M., Klironomos, J. N., Dunfield, K. E., \& Hart, M. M. (2012). The potential of soil amendments for restoring severely disturbed grasslands. Applied Soil Ecology, 60, 77-83. http://dx.doi.org/10.1016/j.apsoil.2012.02.006

Owen, S. C., Hull Sieg, C., Gehring, C. A., \& Bowker, M. A. (2009). Above- and belowground responses to tree thinning depend on the treatment of tree debris. Forest Ecology and Management, 259, 71-80. http://dx.doi.org/10.1016/j.foreco.2009.09.044

Paschke, M. W., McLendon, T., \& Redente, E. F. (2000). Nitrogen availability and old-field succession in a shortgrass steppe. Ecosystems, 3, 144-158. http:// 10.1007/s100210000016

Perry, L. G., Blumenthal, D. M., Monaco, T. A., Paschke, M. W., \& Redente, E. F. (2010). Immobilizing nitrogen to control plant invasion. Oecologia, 163, 13-24. http://dx.doi.org/10.1007/s00442-010 -1580-x

Porazinska, D. L., Bardgett, R. D., Blaauw, M. B., Hunt, H. W., Parsons, A. N., Seastedt, T. R., \& Wall, D. H. (2003). Relationships at the aboveground-belowground interface: plants, soil biota, and soil processes. Ecological Monographs, 73(3), 377-395. http://dx.doi.org/10.1890/0012-9615(2003)073[0377:RATAIP]2.0.CO;2

Prosser, J. I. (2011). Soil nitrifiers and nitrification. In B. B. Ward, D. J. Arp, \& M. G. Klotz (Eds.), Nitrification (pp. 347-383). Washington, DC: ASM Press

Rudrappa, T., Czymmek, K., Pare, P., \& Bais, H. (2008) Root-secreted malic acid recruits beneficial soil bacteria. Plant Physiology, 148(3), 1547-1556. http://dx.doi.org/10.1104/pp.108.127613

Saetre, P., \& Stark, J. (2005). Microbial dynamics and carbon and nitrogen cycling following re-wetting of soils beneath two semi-arid plant species. Oecologia, 142(2), 247-260. http://dx.doi.org/ 10.1007/s00442-004-1718-9

Sayavedra-Soto, L. A., \& Arp, D. J. (2011). Ammonia-oxidizing bacteria: Their biochemistry and molecular biology. In B. B. Ward, D. J. Arp, \& M. G. Klotz (Eds.), Nitrification (pp. 11-37). Washington, DC: ASM Press

Schlesinger, W. H., Raikes, J. A., Hartley, A. E., \& Cross, A. F. (1996). On the spatial pattern of soil nutrients in desert ecosystems. Ecology, 77(2), 364-374. http://dx.doi.org/10.2307/2265615

Schlesinger, W. H., Reynolds, J. F., Cunningham, G. L., Huenneke, L. F., Jarrell, W. M., Virginia, R. A., \& Whitford, W. G. (1990). Biological feedbacks in global desertification. Science, 247, 1043-1048. http://dx.doi.org/10.1126/science.247.4946.1043

Schrey, S. D., \& Tarkka, M. T. (2008). Friends and foes: streptomycetes as modulators of plant disease and symbiosis. Antonie van Leeuwenhoek, 94(1), 11-19. http://dx.doi.org/10.1007/s10482-008-9241-3

Stark, J.M., \& Norton, J.M. (2015). The invasive annual cheatgrass increases nitrogen availability in 24-year-old replicated field plots. Oecologia, 177, 799-809. 
http://dx.doi.org/10.1007/s00442-014-3093-5

Starkenburg, S. R., Spieck, E., \& Bottomley, P. J. (2011). Metabolism and genomics of nitrite-oxidizing bacteria: Emphasis on studies of pure cultures and of Nitrobacter species. In B. B. Ward, D. J. Arp \& M. G. Klotz (Eds.), Nitrification (pp. 267-293). Washington, DC, ASM Press.

Svejcar, T., \& Sheley, R. L. (2001). Nirogen dynamics in perennial- and annual-dominated arid rangeland. Journal of Arid Environments, 47, 33-46. http://dx.doi.org/10.1006/jare.2000.0703

Sylvia, D. M., Fuhrmann, J. J., Hartel, P. G., \& Zuberer, D. A. (2005). Principles and Applications of Soil Microbiology. Upper Saddle River, NJ: Pearson Prentice Hall.

Tarkka, M., Schrey, S., \& Hampp, R. (2008). Plant associated soil micro-organisms. In C. S. Nautiyal, \& P. Dion (Eds.), Molecular Mechanisms of Plant and Microbe Coexistence (pp. 3-51). Berlin, Heidelberg: Springer

Thill, D. C., Beck, K. G., \& Callihan, R. H. (1984). The Biology of downy brome (Bromus tectorum). Weed Science, 32, 7-12. http://www.jstor.org/stable/4043963

Urakawa, H., Martens-Habbena, W., \& Stahl, D. A. (2011). Physiology and genomics of ammonia-oxidizing Archaea. In B. B. Ward, D. J. Arp, \& M. G. Klotz (Eds.), Nitrification (pp. 117-155). Washington, DC: ASM Press

Van der Putten, W. H., Klironomos, J. N., \& Wardle, D. A. (2007). Microbial ecology of biological invasions. The ISME Journal, 1, 28-37. http://dx.doi.org/10.1038/ismej.2007.9

Ward, N. L., Challacombe, J. F., Janssen, P. H., Henrissat, B., Coutinho, P. M., Wu, M., \& et. al. (2009). Three genomes from the phylum Acidobacteria provide insight into the lifestyles of these microorganisms in soils. Applied and Environmental Microbiology, 75(7), 2046-2056. http://dx.doi.org/10.1128/AEM.02294-08

Wardle, D. A., Bardgett, R. D., Klironomos, J. N., Setälä, H., Van der Putten, W. H., \& Wall, D. H. (2004). Ecological linkages between aboveground and belowground biota. Science, 304(5677), 1629-1633. http://dx.doi.org/10.1126/science.1094875

Wu, J., Brookes, P. C., \& Jenkinson, D. S. (1993). Formation and destruction of microbial biomass during the decomposition of glucose and ryegrass in soil. Soil Bilology and Biochemistry, 25(10), 1435-1441. http://dx.doi.org/doi:10.1016/0038-0717(93)90058-J

\section{Glossary}

C: carbon

$\mathrm{CO}_{2}$ : carbon dioxide

$\mathrm{O}_{2}$ : oxygen

$\mathrm{N}$ : nitrogen 
$\mathrm{NH}_{4}^{+}$: ammonium ion

$\mathrm{NH}_{3}$ : ammonia

$\mathrm{NO}_{3}{ }^{-}$: nitrate ion

$\mathrm{NO}_{2}^{-}$: nitrite ion

\section{Copyright Disclaimer}

Copyright for this article is retained by the author(s), with first publication rights granted to the journal.

This is an open-access article distributed under the terms and conditions of the Creative Commons Attribution license (http://creativecommons.org/licenses/by/3.0/). 